\section{Histórias invisíveis do Teatro da Paz: da construção à primeira reforma. Belém do Grão-Pará (1869-1890)}

\author{
Roseane Silveira de Souza \\ silveirissima@gmail.com \\ Dissertação de Mestrado \\ Programa de Estudos Pós-Graduados em História / \\ Pontifícia Universidade Católica de São Paulo \\ São Paulo (SP) 2009
}

A dissertação tem por objetivo principal renovar o sentido da história dos primeiros tempos do Teatro da Paz no tecido urbano de Belém, desvelando e relendo fontes escritas e imagéticas. Seguindo a proposição do historiador Antonio Mitre, renovar o sentido reescrevendo a história já conhecida a partir de uma reinterpretação dos conceitos subjacentes às fontes. As histórias invisíveis do Teatro da Paz incidem sobre aspectos de sua construção (1869-1874), os nove primeiros anos de funcionamento e apropriações públicas (1878-1887), e sua primeira reforma (1887-1890), que, segundo a hipótese que norteia o trabalho, foram sombreados como efeito de uma outra reforma, realizada entre 1904 e 1905, que transformou interna e externamente a edificação, sendo esta a sua imagem consolidada. Esta reforma, empreendida sob uma perspectiva positivista republicana e de importação de valores culturais europeus, teve como motivação política promover o esquecimento do passado vinculado à Monarquia, considerada sinônimo de atraso cultural. A pesquisa se insere no campo da História Social pelo viés da História Cultural, sob a perspectiva do estudo das representações. Por isso mesmo, tem vínculos com os estudos de história urbana e, por extensão, de cultura material. São abordados, entre outros, os conceitos de monumento, patrimônio histórico, obras públicas, público e imagem. Foram utilizados como fontes documentos da Administração do Teatro da Paz entre 1882 e 1899; relatórios de governo, falas e discursos de presidentes da província e governadores do estado; jornais dos séculos XIX e XX; impressos institucionais; a planta da cidade de Belém de 1771 e as pinturas artísticas da sala de espetáculos do teatro, de autoria de Domenico de Angelis e Chrispim do Amaral. Finalmente, a pesquisa apresenta outras perspectivas aos estudos sobre o Grão-Pará e sobre um dos principais monumentos erguidos no século XIX, durante a chamada Era da Borracha.

\section{Invisible histories of Teatro da Paz: from the building to the first renovation. Belém, Province of Pará (1869-1890)}

\author{
Roseane Silveira de Souza \\ silveirissima@gmail.com \\ Master Dissertation \\ Post-Graduate Studies Program in History / \\ Pontifical Catholic University of São Paulo \\ São Paulo (SP) - Brazil 2009
}

The dissertation aims to get a renewed sense over the early times of Teatro da Paz ('Peace Theater'), an opera house in the urban design of Belém, the capital of former Province of Pará (now Pará State), by revealing and rereading written sources and also images. Following the historian Antonio Mitre, it means to rewrite this history by reinterpretating essential concepts through the sources. Invisible histories refer to three different facts registered from 1869 to 1890 : the construction of the theater (1869-1878), the opening and the public uses for nine years (1878-1887) and the first renovation (1887-1890). According the author's hypothesis, some aspects of these facts were hidden under the official history of the theater as a result of another renovation occurred fourteen years later, between 1904 and 1905, when the building was completely changed in its appearance, consolidating this new image so far. Early republicans in Pará, motivated by the Positivist Thought, have intended to blur the past and the images in the city associated to collapsed Monarchy as a synonym of cultural decline. It was a kind of forgetfulness policy in order to establish a new way of life in the capital, based on European 
social values, and what they have considered progress and a modern life. This research comprehends studies of Social History, embracing the field of Cultural History, specially the concept of representation, and so the territories of urban history and material culture. Concepts as monument, cultural heritage, public buildings, public and image are also involved in. The sources are official documents from Administration Office of Teatro da Paz (1882 to 1899); official speeches and reports produced by presidents of the former Province of Pará and also by governors of Pará State; 19th-and-20th-century newspapers of Pará; official printed documents; the Plan of Belém in 1771; and Chrispim do Amaral and Domenico de Angelis' artistic pictures inside auditorium. Finally, the research points to other studies about Province of Pará and also about one of its principal monuments built during the rubber era. 


\section{Interpretação ambiental e envolvimento comunitário: ecoturismo como ferramenta para a conservação do boto-vermelho, Inia geoffrensis}

\author{
Fernanda Carneiro Romagnoli \\ feromagnoli@ig.com.br \\ Dissertação de Mestrado \\ Programa de Pós-Graduação em \\ Biologia de Água Doce e Pesca Interior \\ Instituto Nacional de Pesquisas da Amazônia \\ Manaus (AM) 2009
}

O turismo voltado à observação de baleias e golfinhos cresce rapidamente em todo o mundo. Esta atividade é considerada como potencial medida de conservação; no entanto, se desordenada, pode causar efeito inverso. Na Amazônia, a espécie-alvo é o boto-vermelho, Inia geoffrensis. As ameaças a esta espécie têm aumentado significativamente, o que inclui o turismo desordenado. Diante da necessidade de se adotar medidas para sua conservação, o "ecoturismo" pode ser uma ferramenta útil. Um de seus fundamentos é promover a sensibilização ambiental de turistas e moradores locais, de modo a que contribuam com a conservação. Os resultados deste estudo evidenciaram que o turismo envolvendo o boto-vermelho em duas áreas no estado do Amazonas não tem contribuído satisfatoriamente para a sensibilização desses atores. Assim, vemos uma grande, mas inexplorada oportunidade para se trabalhar a educação ambiental para a promoção da conservação deste golfinho. Por isso, foram traçadas propostas para o ordenamento do turismo envolvendo o boto-vermelho.

\section{Environmental interpretation and involvement of local residents: ecotourism as a tool in river dolphin conservation, Inia geoffrensis}

\author{
Fernanda Carneiro Romagnoli \\ feromagnoli@ig.com.br \\ Master Dissertation \\ Post-Graduate Program in Fresh Water Biology and Fishery \\ National Institute for Research in the Amazon \\ Manaus (AM) - Brazil 2009
}

Tourism aimed at observing whales and dolphin (commonly referred to as "whale watching") is growing rapidly throughout the world. This kind of tourism is often cited as having conservation potential, however when carried out improperly it can even have a negative effect. In the Amazon, the main species of aquatic mammal sought out for observational tourism is the pink river dolphin (boto in Portuguese), Inia geoffrensis. Threats to the species have increased significantly in recent years, and poorly organized tourism is considered one potential threat. The paradigm of ecotourism has been suggested as a useful tool in promoting conservation measures. This research shows that river dolphin tourism in two regions of Amazonas state in the Brazilian Amazon does not contribute in a satisfactory manner to improving conservation awareness of various local actors and the tourists themselves. Instead, we find a tremendous but poorly exploited potential to use river dolphin tourism for environmental education and conservation promotion. In this context we propose measures for better organizing river dolphin tourism in the Amazon and improving its relevance to the conservation of this emblematic and threatened species.

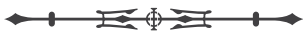




\section{A dinâmica do mercado de frutas tropicais no estado do Pará: uma abordagem econométrica}

\author{
Lindaura Arouck Falesi \\ lindaura@ufpa.br \\ Tese de Doutorado \\ Programa de Pós-Graduação em Ciências Agrárias \\ Universidade Federal Rural da Amazônia \\ Belém (PA) 2009
}

A fruticultura no estado do Pará e na mesorregião Nordeste Paraense, no período de 1985 a 2005, é analisada em relação à fruticultura brasileira e regional, indicando o nível de contribuição como atividade econômica. Os resultados, com base no modelo econométrico, apontaram importante participação estadual na produção frutícola brasileira, com significativos resultados para os índices de crescimento estadual e mesorregional. $\bigcirc$ desempenho da mesorregião Nordeste Paraense foi importante, justificando a posição de pólo de referência para a fruticultura no Pará. A análise do mercado de frutas frescas estadual, com base no comportamento da dinâmica do mercado, indicou ser a fruticultura uma atividade econômica promissora como oportunidade de negócio em franca expansão. A produção gerada ainda direciona-se em grande parte para o abastecimento do mercado paraense, deixando uma demanda insatisfeita em nível regional e nacional. À exceção de algumas frutíferas, como açaí, abacaxi, banana, maracujá e cupuaçu, que se destacam no mercado nacional, as demais são cultivadas em quintais, em pequenas áreas ou extraídas diretamente da floresta nativa. A dinâmica do mercado de frutas foi estudada com base no modelo dinâmico de equações simultâneas, estimado pelo Método dos Momentos
Generalizados - MMG. Estes resultados evidenciaram a demanda de frutas no estado do Pará como inelástica a preço. A mesorregião Nordeste Paraense, com elevado índice de concentração de frutas frescas, é suporte para o abastecimento das agroindústrias de beneficiamento de polpas de frutas, com participação média em torno de 60\% da produção estadual. Os efeitos das variáveis estudadas, no modelo, e as respostas das elasticidadespreços, da demanda e oferta, foi de comportamento inelástico a preço. As elasticidades renda e cruzada da oferta e da demanda de frutas, na mesorregião Nordeste Paraense, em relação a outras lavouras, apresentaram oferta inelástica a preço, incluindo ambas as lavouras permanentes e temporárias. A oferta foi negativamente relacionada a incrementos no salário rural e a preço de outras lavouras. Assim, a oferta de frutas poderá se expandir com a incorporação de tecnologia direcionada, ou se retrair com o aumento da mão-de-obra empregada. O extrativismo de frutas, representado pelo açaí e pela castanha-do-pará, indicou o comportamento da demanda e da oferta defasada, inelásticas a preço. $\bigcirc$ crescimento da fruticultura no estado do Pará, superando as dificuldades, como barreiras fitossanitárias e cambiais, consolida-se como grande vetor de desenvolvimento econômico, sendo ponto favorável de crescimento a diversidade de frutas na sua base agrária. O mercado de frutas é promissor, porém há desequilíbrio entre a oferta e a demanda de frutas, caracterizado pela escassez de oferta. $\bigcirc$ incentivo à produção, bem como a melhoria na qualidade de vida da sociedade, nas últimas décadas, contribuiu para a valorização das frutas como fonte de energia e saúde. O desenvolvimento sustentável da economia frutícola, no estado do Pará, dependerá da consolidação de pólos agroindustriais integrados à atividade.

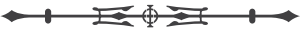




\section{The dynamics of tropical fruits market in Pará State, Brazil: an econometrics approach}

\author{
Lindaura Arouck Falesi \\ lindaura@ufpa.br \\ Doctoral Thesis \\ Post-Graduate Program in Agrarian Sciences \\ Federal University of Rural Amazonian \\ Belém (PA) - Brazil 2009
}

From 1985 to 2005 fruit growing in Pará State and in the Northeastern Pará region, in Brazil, is compared to regional and Brazilian fruit growing, indicating its level of contribution as an economic activity. Results based on econometric have pointed important State contribution to Brazilian fruit production with significant state and regional index growth. Northeastern Pará development was important and has justified a reference position to fruit culture in the State. The State market of fresh fruit analysis based upon market dynamics has indicated fruit culture to be a promising economic opportunity in continuous expansion. The production is still largely focused on State market, leaving an unsatisfied demand at regional and national level. Except for fruits such as açai, banana, pineapple, passion fruit and cupuaçu, well positioned at national market, the others are cultivated in gardens or small areas as well as directly extracted from the native forest. The performance of fruit market was studied based on simultaneous equation dynamic model, estimated by
Generalized Method of Moments - GMM. Results have shown fruit demand in the Pará State as price statics. The Northeast Pará region has shown a high concentration of fresh fruits, being the support to supply fruit pulp for agroindustries with participation in State production around $60 \%$. Effects of studied model varieties and the answer of price-elasticity of demand and offer had an inelastic price behavior. Income elasticity crossed by offer and demand of fruits in Northeastern Pará region in relation to other crops have presented an inelastic price offer including both permanent and temporary tillage. Offer was negative related to rural salary increments and to other tillage prices. Thus, the fruit offer may expand with specific technology insertion or should retract with the increase of employments. Fruit extraction represented by açai and Brazil-nut has indicated delayed demand and offer price inelastic. The growth of fruit culture on the State of Pará, undertaking difficulties such as phytosanitary regulation and monetary variation, has consolidated as great vector of economic development, being the diversity of fruits of its agrarian base for its growth. The fruit market is promising, although there is unbalance between offer and demand, characterized by offer shortage. Incentive to production as well as improvement in society's life quality in the last decades contributed to valorization of fruits as a source of energy and health. The sustainable development of fruit culture economy in the State of Pará will rely on consolidation of agroindustrial poles integrated to the activity.

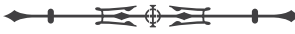


